\title{
Eroded Agriculture Land Conservation Method Based on Dose Response Economic Valuation for Sustainable Land Maintain: A Case Study in Bompon Watershed, Magelang, Central Java
}

\author{
Shinta Devi Wulan Sari ${ }^{1 *}$ and Vicka Larasati Purdadi ${ }^{2}$, Member, IAE
}

\begin{abstract}
Central Java has unique watershed that located in Magelang. Bompon watershed has kind of material that decayed of volcano dust parental material which the material was influence by alteration process, placed at hilly morphology, and produce very thick soil. Erosional process cause loss of some nutrients, especially nitrogen potentially occur in this type of soil. Erosion and data survey processed by dose response method are the main procedure of the research. Dose response method can be used to determine the financial loss occur by the erosional process, and $\mathrm{Rp} \mathrm{12,934,024}$ (around 994.923 USD) is financial loss because of the erosional process in each hectare of agricultural land. Conservations are better chosen as the solution to maintain the sustainability of the agricultural land in order to protect from decreasing productivity, besides it has cheap price equal to the financial loss occur. Best conservations suggested to be applied are combining the vegetative and physical method, which are planting peanut and making tight ridges.
\end{abstract}

Keywords - dose-response, erosion, conservation

\section{INTRODUCTION}

$\mathrm{B}$ OMPON watershed located in Magelang, Central Java has uniqueness where the materials was decayed of volcano dust parental material which the material was influence by alteration process, produce very thick soil, and placed at hilly morphology [1]. Thick soil supported by placed at hilly morphology are potentially cause erosional process and agricultural land degradation impacted to decreasing land productivity [2]. Land is the main capital of agricultural process, this might be really disadvantageous in case the land capacity decreased. This condition gives disadvantages to farmers in Bompon watershed where the land are used to be agricultural area. The disadvantages of soil erosion that cause soil nutrient loss oftentimes slighted by farmers, while this condition continuously occur.

Shinta Devi Wulan Sari ${ }^{1}{ }^{1}$ Environmental Geography Department, Faculty of Geography, Universitas Gadjah Mada Bulaksumur, Sleman, Yogyakarta *shinta.devi.w@mail.ugm.ac.id, telp.: +62812-7823-2291

Vicka Larasati Purdadi ${ }^{2}$ 2Agronomy Department, Faculty of Agriculture, Universitas Gadjah Mada Bulaksumur, Sleman, Yogyakarta
Dose-response approach in its most basic form looks at environmental resources which lead to a marginal change in the output of good sold on a competitive market and values the impact directly in terms of output changes valued at market price [3]. Dose-response valuation has been used to value affect of air pollution on health, physical depreciation of material assets such as metal and building, aquatic ecosystems, vegetation and soil erosion [4].

Soil aggregation is one of the most important dynamic properties of soils to be considered by the investigator dealing with soil tilth, erosion control, and other problems in soil physics [5]. Erosion occurs when soil is left exposed to rain or wind energy. Raindrops hit exposed soil with great energy and easily dislodge the soil particles from the surface. In this way, raindrops remove a thin film of soil from the land surface and create what is termed sheet erosion. The impact of soil erosion is intensified on sloping land, where often more than half of the surface soil is carried away as the water splashes downhill into valleys and waterways. Wind energy also has great power to dislodge surface soil particles, and transport them great distances. Loss of soil vegetative cover is especially widespread in developing countries where populations are large, and agricultural practices are often inadequate to protect top soils [6].

Sustaining or increasing soil productivity depends in part on soil and crop management practices that maintain or increase soil organic matter. Crop production practices such as tillage, residue management, crop rotation, and $\mathrm{N}$ fertilization also influence organic-matter levels in soils. Soil organic $\mathrm{N}$ in both soils decreased with increasing frequency of soybean in the rotation, because soybean generally depletes soil $\mathrm{N}$ [7].

In organic agriculture, intercropping is receiving increasing attention as it offers potential advantages for increasing sustainability in crop production [8].Intercropping is a cultural practice which increases competition between crops and weeds. It can increase light interception in a weakly competitive crop and can contribute to weed suppression in a long-term strategy for weed management [9] 


\section{II.METHOD}

\section{A. Erosion Measuring and Survey}

Erosions are rapidly happen caused by water and supported by hilly morphology of the watershed that made intensive erosion process. Survey focused on measuring the morphometric of the erosion which the data will use to determine the volume of soil loss. Erosion survey took place at the slope of the hill where the agricultural process occurred intensively. Width, length, and depth are the important component measured. Survey method used is erosion reconnaissance. This method determined soil loss from direct measurement erosion dimension and shape.

\section{B. Data Processing}

Erosion survey data processes using calculation method. Morphometric data of the erosion is the basic data to determine average wide, volume, and soil loss of the erosion. Bulk density provided by Transbulent nature laboratory in Bompon Watershed which is managed by Faculty of Geography lectures and assistant.

\section{Calculating Financial Loss}

Data survey processed output is volume of soil loss caused by the erosion. This data will use to calculate the financial loss using doss response method. Basic principle of dose response method is equalized natural process with some replacement parameter. In this case, the loss of soil nutrient $(\mathrm{N})$ equalized to fertilizer price which is used for increasing nutrient in the soil. These are formulas used:

$$
\begin{aligned}
& \mathrm{A}=(\mathrm{W} * \mathrm{D}) / 2 \\
& \mathrm{~V}=\mathrm{W} * \mathrm{D} * \mathrm{~L} \\
& \mathrm{SL} 1=\mathrm{V} / \mathrm{LC} \\
& \mathrm{SL} 2=(\mathrm{SL} 1 * \mathrm{BD}) / 10^{4}
\end{aligned}
$$

\begin{tabular}{|c|c|c|c|c|c|}
\hline \multirow{2}{*}{ No } & \multicolumn{2}{|c|}{ Coordinat (UTM) } & \multicolumn{3}{|c|}{ Morphometry (m) } \\
\hline & $\mathbf{X}$ & $\mathbf{Y}$ & $\mathbf{W}$ & D & $\mathbf{L}$ \\
\hline 1 & 396985 & 9163815 & 0,28 & 0,31 & 2,82 \\
\hline 2 & 396980 & 9163827 & 1,76 & 0,25 & 5,83 \\
\hline 3 & 396985 & 9163831 & 2,66 & 0,28 & 7,96 \\
\hline 5 & 396967 & 9163852 & 0,90 & 0,26 & 1,00 \\
\hline 6 & 396964 & 9163853 & 0,30 & 0,11 & 4,08 \\
\hline 7 & 396970 & 9163857 & 0,83 & 0,35 & 2,54 \\
\hline 8 & 396973 & 9163855 & 0,75 & 0,46 & 2,02 \\
\hline 10 & \multirow{3}{*}{396941} & \multirow{3}{*}{9163872} & \multirow{3}{*}{0,86} & \multirow{3}{*}{0,06} & \multirow{3}{*}{6,30} \\
\hline 11 & & & & & \\
\hline 12 & & & & & \\
\hline 13 & \multirow{3}{*}{397017,94} & \multirow{3}{*}{9163884,2} & 0,24 & 0,28 & 4,50 \\
\hline 14 & & & \multirow{2}{*}{0,13} & \multirow{2}{*}{0,13} & \multirow{2}{*}{2,70} \\
\hline 15 & & & & & \\
\hline
\end{tabular}

\section{Erosion Measurement:}

TABLE 1.

EROSION MEASUREMENT

\begin{tabular}{|l|}
\hline 16 \\
\hline 17 \\
\hline 18 \\
\hline 19 \\
\hline 20 \\
\hline 21 \\
\hline 22 \\
\hline 23 \\
\hline 24 \\
\hline 25 \\
\hline 26 \\
\hline 27 \\
\hline 28 \\
\hline 29 \\
\hline 30 \\
\hline 31 \\
\hline 32 \\
\hline
\end{tabular}

\begin{tabular}{|l|l|l|}
0,07 & 0,11 & 1,40 \\
\hline 0,14 & 0,16 & 0,90 \\
\hline 0,12 & 0,17 & 2,40 \\
\hline 0,30 & 0,21 & 1,90 \\
\hline 0,13 & 0,15 & 1,30 \\
\hline 0,13 & 0,10 & 1,00 \\
\hline 0,13 & 0,07 & 0,40 \\
\hline 0,09 & 0,09 & 0,60 \\
\hline 0,06 & 0,08 & 1,40 \\
\hline 0,03 & 0,12 & 4,30 \\
\hline 0,07 & 0,05 & 5,00 \\
\hline 0,15 & 0,14 & 2,90 \\
\hline 0,10 & 0,06 & 1,40 \\
\hline 0,22 & 0,16 & 0,80 \\
\hline 0,12 & 0,14 & 0,70 \\
\hline
\end{tabular}

Source: Field Survey, 2017

Additional Information:

$$
\begin{aligned}
\mathrm{W} & =\text { Width } \\
\mathrm{D} & =\text { Depth } \\
\mathrm{L} & =\text { Length }
\end{aligned}
$$

\begin{tabular}{|c|c|c|c|c|c|c|}
\hline \multirow{2}{*}{$A\left(\mathbf{m}^{2}\right)$} & \multirow{2}{*}{$\underset{\left(\mathbf{m}^{3}\right)}{V}$} & \multirow{2}{*}{$\begin{array}{l}\mathbf{L C} \\
\left(\mathbf{m}^{2}\right)\end{array}$} & \multirow{2}{*}{$\begin{array}{c}\text { SL 1 } 1 \\
\left(\mathbf{m}^{3} / \mathbf{m}^{2}\right)\end{array}$} & \multicolumn{2}{|c|}{ BD } & \multirow{2}{*}{$\begin{array}{c}\text { SL 2 } \\
\text { (t/ha) }\end{array}$} \\
\hline & & & & $\mathrm{g} / \mathrm{cm}^{3}$ & t/ha & \\
\hline 0,0434 & $\begin{array}{l}0,12 \\
2388\end{array}$ & \multirow{7}{*}{1.3} & $\begin{array}{c}0,094144 \\
6\end{array}$ & 1,06 & 10,6 & $\begin{array}{c}0,000099 \\
7933\end{array}$ \\
\hline 0,22 & $\begin{array}{c}, 28 \\
26\end{array}$ & & $\begin{array}{c}0,986615 \\
4 \\
\end{array}$ & 1,06 & 10,6 & $\begin{array}{c}0,001045 \\
8123\end{array}$ \\
\hline 0,3724 & $\begin{array}{l}2,96 \\
4304 \\
\end{array}$ & & $\begin{array}{c}2,280233 \\
8 \\
\end{array}$ & 1,06 & 10,6 & $\begin{array}{c}0,002417 \\
0479 \\
\end{array}$ \\
\hline 0,117 & $\begin{array}{c}0,11 \\
7 \\
\end{array}$ & & 0,09 & 1,06 & 10,6 & $\begin{array}{c}0,000095 \\
4000\end{array}$ \\
\hline 0,0165 & $\begin{array}{l}0,06 \\
732 \\
\end{array}$ & & $\begin{array}{c}0,051784 \\
6 \\
\end{array}$ & 1,06 & 10,6 & $\begin{array}{c}0,000054 \\
8917 \\
\end{array}$ \\
\hline $\begin{array}{c}0,1452 \\
5 \\
\end{array}$ & $\begin{array}{l}0,36 \\
8935\end{array}$ & & $\begin{array}{c}0,283796 \\
2 \\
\end{array}$ & 1,06 & 10,6 & $\begin{array}{c}0,000300 \\
8239\end{array}$ \\
\hline 0,1725 & $\begin{array}{l}0,34 \\
845 \\
\end{array}$ & & $\begin{array}{c}0,268038 \\
5 \\
\end{array}$ & 1,06 & 10,6 & $\begin{array}{c}0,000284 \\
1208 \\
\end{array}$ \\
\hline 0,0258 & $\begin{array}{l}0,16 \\
254 \\
\end{array}$ & \multirow{9}{*}{1,3} & $\begin{array}{c}0,125030 \\
8 \\
\end{array}$ & 1,06 & 10,6 & $\begin{array}{c}0,000132 \\
5326\end{array}$ \\
\hline 0,0336 & $\begin{array}{c}0,15 \\
12 \\
\end{array}$ & & $\begin{array}{c}0,116307 \\
7 \\
\end{array}$ & 1,09 & 10,9 & $\begin{array}{c}0,000126 \\
7754 \\
\end{array}$ \\
\hline \multirow{2}{*}{$\begin{array}{c}0,0081 \\
25\end{array}$} & \multirow{2}{*}{$\begin{array}{c}0,02 \\
1937 \\
5\end{array}$} & & \multirow{2}{*}{0,016875} & 1,09 & 10,9 & \multirow{2}{*}{$\begin{array}{c}0,000018 \\
3938\end{array}$} \\
\hline & & & & 1,09 & 10,9 & \\
\hline $\begin{array}{c}0,0038 \\
5 \\
\end{array}$ & $\begin{array}{l}0,00 \\
539 \\
\end{array}$ & & $\begin{array}{c}0,004146 \\
2 \\
\end{array}$ & 1,09 & 10,9 & $\begin{array}{c}0,000004 \\
5193 \\
\end{array}$ \\
\hline \multirow{2}{*}{$\begin{array}{c}0,0038 \\
5\end{array}$} & \multirow{2}{*}{$\begin{array}{l}0,00 \\
3465\end{array}$} & & \multirow{2}{*}{$\begin{array}{c}0,002665 \\
4\end{array}$} & 1,09 & 10,9 & \multirow{2}{*}{$\begin{array}{c}0,000002 \\
9053\end{array}$} \\
\hline & & & & 1,09 & 10,9 & \\
\hline 0,0102 & $\begin{array}{l}0,02 \\
448 \\
\end{array}$ & & $\begin{array}{c}0,018830 \\
8\end{array}$ & 1,09 & 10,9 & $\begin{array}{c}0,000020 \\
5255\end{array}$ \\
\hline 0,0315 & $\begin{array}{l}0,05 \\
985\end{array}$ & & $\begin{array}{c}0,046038 \\
5\end{array}$ & 1,09 & 10,9 & $\begin{array}{c}0,000050 \\
1819\end{array}$ \\
\hline
\end{tabular}

Erosion Data Processing:

TABLE 2.

EROSION DATA PROCESSING 


\begin{tabular}{|c|c|c|c|c|c|}
\hline $\begin{array}{c}0,0097 \\
5\end{array}$ & $\begin{array}{l}0,01 \\
2675\end{array}$ & 0,00975 & 1,09 & 10,9 & $\begin{array}{c}0,000010 \\
6275\end{array}$ \\
\hline 0,0065 & $\begin{array}{c}0,00 \\
65\end{array}$ & 0,005 & 1,09 & 10,9 & $\begin{array}{c}0,000005 \\
4500\end{array}$ \\
\hline $\begin{array}{c}0,0045 \\
5\end{array}$ & $\begin{array}{c}0,00 \\
182\end{array}$ & 0,0014 & 1,09 & 10,9 & $\begin{array}{c}0,000001 \\
5260\end{array}$ \\
\hline $\begin{array}{c}0,0038 \\
25\end{array}$ & $\begin{array}{l}0,00 \\
2295\end{array}$ & $\begin{array}{c}0,001765 \\
4\end{array}$ & 1,09 & 10,9 & $\begin{array}{c}0,000001 \\
9243\end{array}$ \\
\hline 0,0024 & $\begin{array}{l}0,00 \\
336\end{array}$ & $\begin{array}{c}0,002584 \\
6\end{array}$ & 1,09 & 10,9 & $\begin{array}{c}0,000002 \\
8172\end{array}$ \\
\hline 0,0018 & $\begin{array}{l}0,00 \\
774\end{array}$ & $\begin{array}{c}0,005953 \\
8\end{array}$ & 1,09 & 10,9 & $\begin{array}{c}0,000006 \\
4897\end{array}$ \\
\hline $\begin{array}{c}0,0017 \\
5\end{array}$ & $\begin{array}{l}0,00 \\
875\end{array}$ & $\begin{array}{c}0,006730 \\
8\end{array}$ & 1,09 & 10,9 & $\begin{array}{c}0,000007 \\
3365\end{array}$ \\
\hline \multirow{2}{*}{$\begin{array}{c}0,0017 \\
5\end{array}$} & \multirow{2}{*}{$\begin{array}{l}0,00 \\
5075\end{array}$} & \multirow{2}{*}{$\begin{array}{c}0,003903 \\
8\end{array}$} & 1,09 & 10,9 & \multirow{2}{*}{$\begin{array}{c}0,000004 \\
2552\end{array}$} \\
\hline & & & 1,09 & 10,9 & \\
\hline 0,003 & $\begin{array}{c}0,00 \\
42\end{array}$ & $\begin{array}{c}0,003230 \\
8\end{array}$ & 1,09 & 10,9 & $\begin{array}{c}0,000003 \\
5215\end{array}$ \\
\hline 0,0176 & $\begin{array}{l}0,01 \\
408\end{array}$ & $\begin{array}{c}0,010830 \\
8\end{array}$ & 1,09 & 10,9 & $\begin{array}{c}0,000011 \\
8055\end{array}$ \\
\hline 0,0084 & $\begin{array}{c}0,00 \\
588\end{array}$ & $\begin{array}{c}0,004523 \\
1\end{array}$ & 1,09 & 10,9 & $\begin{array}{c}0,000004 \\
9302\end{array}$ \\
\hline
\end{tabular}

Source: Field Survey, 2017

Additional Information:
A (m2)
$=$ Area of erosion $(\{\mathrm{W} \times \mathrm{D}\} / 2)$
$\mathrm{V}(\mathrm{m} 3)$
$\mathrm{LC}(\mathrm{m} 2)$
BD
SL1 (m3/m2)
SL2 (t/ha)
$=$ Volume of erosion (W $\times$ D x L)
$=$ Catchment area
$=$ Bulk Density
$=$ Volume of soil eroded in $\mathrm{m} 3 / \mathrm{m} 2$
Total of SL2 $=0.004714407 \mathrm{ton} / \mathrm{ha} \approx 4.7144073 \mathrm{~kg} / \mathrm{ha}$
Total of LC $=0.0039$ ha

\section{Financial Loss and Conservation Cost:}

\section{i. Financial Loss}

Dose response is a method to convert environmental degradation process become having economic values. Environmental degradation occurred is soil nutrient (N) decreased. This degradation type can be equalized to fertilizer needed to revert as the land was.

Nutrient soil loss (Rp) $[\mathrm{A}]=$ Specific nutrient loss $(\mathrm{N})$ per unit area $(\mathrm{kg} / \mathrm{ha})[\mathrm{B}] \mathrm{x}$ Price of fertilizer (Rp) [C] x Total area (ha) [D]

Data:

$$
\begin{aligned}
\mathrm{B} & =\mathrm{N} \text { proportion } \mathrm{x} \text { soil loss in degraded area } \\
& =167.97 \mathrm{x} 4.7144073 \\
& =791.8789942 \mathrm{~kg} / \mathrm{ha}
\end{aligned}
$$

* $1 \mathrm{~kg}$ fertilizer contain $0.3 \mathrm{~kg}$ of nitrogen

Nitrogen loss compared to nitrogen contain in fertilizer $=791.8789942 / 0.3$

$\mathrm{B}=2,639.596647 \mathrm{~kg} / \mathrm{ha}$

$\mathrm{C}=\operatorname{Rp} 4,900 / \mathrm{kg}$

$\mathrm{D}=0.00013$ ha

Final calculation:

$\mathrm{A}=2,639.596647 \times 4,900 \times 0.00013$

$\mathrm{A}=\mathrm{Rp} 1,681.42$ per 0.00013 ha

$\mathrm{A}=\operatorname{Rp} 12,934,024$ (USD 994.923) per ha

\section{ii. Conservation Cost}

TABLE 3.

VEgetaTIVE CONSERVATION COST

\begin{tabular}{|l|l|}
\hline Needs & Price \\
\hline Seed 200 kilos @ Rp 4000 & Rp. 800,000 (USD 61.54) \\
\hline Harvest basket & Rp.121,500 (USD 9.35) \\
\hline Balance machine & Rp. 148,500 (USD 11.42) \\
\hline Water pump & Rp. 728,000 (USD 56) \\
\hline Mattock & Rp. 161,500 12.42) \\
\hline Wagon & Rp. 228,300 (USD 17.56) \\
\hline Operational cost total & Rp. 2,187,800 (USD \\
& 168.3 ) \\
\hline
\end{tabular}

TABLE 4.

PHYSICAL CONSERVATION COST

\begin{tabular}{|l|l|}
\hline Needs & Price \\
\hline Labour (30) @ Rp. 30000 & Rp. 900,000 (USD 69.23) \\
\hline Mattock (5) @ Rp. 60000 & Rp. 300,000 (USD 23.07) \\
\hline Operational cost total & Rp 1,200,00 (USD 92.3) \\
\hline
\end{tabular}

Total Cost $=\operatorname{Rp} 3,387,800($ USD 260.6)

\section{DISCUSSION}

Bompon Watershed land intensively used as agricultural area and managed by local farmers. Planting system applied in rotation circulation depending on local season and farmer's modal. The soil type and hilly topography cause intensive erosion process. Soil erosion is a natural process, many human activities have increased rates of soil erosion. Soil erosion reduces soil productivity, scars the landscape, and causes downstream damage. Sediment accumulation in water bodies affects water quality, causes loss of storage capacity, affects biological activity, and reduces recreational potential [10]. The most excessive one in this area are rill erosion type. Erosion survey headed in 1,3 $\mathrm{m} 3$ wide area in the slope of the hill. Impacts of intensive rill erosion occur are sediment gaining from the top soil part. Topsoil is the upper soil which is being transported and loss, in the other hand this art of soil is the most fertile soil because contain soil nutrient/organic matter. Loss of topsoil reduces soil fertility which impact to productivity decreased. The most important soil nutrients are nitrogen $(\mathrm{N})$, phosphor $(\mathrm{P})$, and potassium $(\mathrm{K})$, while $\mathrm{N}$ is in the biggest proportion than the others. Nitrogen chosen as the indicator for calculating the financial loss cause by rill erosion because it importance and it easiness to substitute by fertilizer.

Nitrogen decreased indicating land degradation process. Land as the main financial capital and fix cost are the important part to maintain the agricultural activities. Agriculture areas are vital modal to get maximum yield. Quality and quantity of the land need to be protected from degrading. Farmers oftentimes slighted agriculture land condition, meanwhile the agricultural process continually afforded. Natural process occur carry as so the land condition changes every time, better or worst. Natural process supported by humanity activities mostly effect to decreasing quality and quantity of the land, which is substantively cause financial loss. Converting environmental degradation to financial loss is one of strategy to show economic value of nature to farmers so they realize how important of land condition is. In this case, 
environmental degradation converted to financial loss using dose-response approach.

The converting result notifies that $\mathrm{Rp} 12,934,024$ (994.923 USD) is the financial loss of soil erosion in each hectare of Bompon Watershed. Calculation result figures that every hectare soil land eroded, financial loss arise quite high. Financial loss procurable from equalizing soil nutrient loss $(\mathrm{N})$ with fertilizer needed to reinstate the soil nutrient. The loss of soil nutrients (specially nitrogen) cause by erosion gives very bad impact to amount of the yields, beside the quantitative either the qualitative. Plants couldn't get the optimum nutrients to full fill their needs in vegetative and generative phase, in hence the yields decrease. Farmers are the nearest to be related to, they get the disadvantages. Most of farmer using fertilizer to add nitrogen consumption and other important nutrients. Giving fertilizer would make the production cost higher, besides it will impact the land quality. Soil erosion by water must be seen as an important global environmental problem and there is an urgent need for quantitative information on rates of soil denudation, both for assessing the problem and devising and implementing improved soil conservation and land management strategies [11]. To prevent increase of the cost and maintain the land condition, it's suggested to apply conservation.

Conservation suggested applied in research area are combining vegetative and physical conservation. Vegetative conservation applying plant as the organism could reinstate nutrients. Peanut (Arachis hypogaea) is an economically important crop because of its widespread commercial production and utilization as oil, food and fiber. Over twothirds of the global peanut production occurs in seasonally rain-fed regions, where drought is a potential constraint for crop production [12]. Peanut (Arachis hypogaea) is one of crop that could bind nitrogen from the atmosphere and release it to soil in order to used by plants. In vegetative conservation peanut will cultivated in intercropping system with any other C4 plant (example: corn). In hence, the suggested advantages of this cropping system include yield stability under adverse environmental conditions, efficient use of limited growth resources, biological diversity, and potential control of pests and diseases [13]. In Applying intercropping system the farmer should pay attention to the kind of the crop. Peanut is one of C3 plant which is best to cultivated with corn (Zea mays) as $\mathrm{C} 4$ plant in intercropping system. There are some indicators to consider, eg: nutrients needed, water needed, long intensity of sun radiation. Legume-cereal intercropping, i.e. the practice of growing two (or more) crops simultaneously in the same land area, offers a potential method of reducing inputs such as fertilizers [14]. Applying vegetative conservation with peanut as the plants only spend Rp. 2,187,800 (USD 168.3) /ha/3 months.

One of the conservation's components is physical works to catch, guide and prevent demage by run-off [15]. For example the use of tied ridges to catch and guide run off and prevent demage to the crops. This physical conservation would only spend around Rp. 1,200,000 (USD 92.3)/ ha/ 3 months. Total cost of combining vegetative and physical conservation to spend would only Rp 3,387,800 (USD 260.6), it's much lighter compare to $\mathrm{Rp}, 12,934,024$ (USD 994.923) /ha financial loss and farmer suffered without conservation.

\section{CONCLUSION}

Through this research we can conclude that the financial loss priced Rp 12,934,024 (around 994.923 USD) per hectare. Conservation method suggested applied in this area are combination between vegetative and physical method, which are plating peanut and making tied ridges. Conservation cost are cheaper compare to the financial loss, hence the conservation are better chosen to maintain the sustainability of the agriculture land.

\section{V.ACKNOWLEDGMENT}

We thank to Allah SWT for Allah blessing so this research could finish in time and very experiencing, henceforth we also thank our parents who always give their best support and pray.

\section{REFERENCES}

[1] Sambodo, Ahmed P. 2016. Perhitungan Nilai Ambang Batas Erosi dengan Metode Modified Productivity Index di Daerah Aliran Sungai Bompon, Kabupaten Magelang, Jawa Tengah. Skripsi. Universitas Gadjah Mada: Yogyakarta

[2] Wahyudi, T., T.R. Panggabean, dan Pujiyanto. 2008. Panduan Lengkap Kakao. Penebar Swadaya: Jakarta and Arsyad, Sitalana. 2009. Konservasi Tanah dan Air: Edisi Kedua. IPB Press: Bogor

[3] Pearce, David., Dominic Moran. 1994. The Economic Value of Biodiversity. Earthscan Publication: UK

[4] ExternE,1995,1999; Markandya and Pavan, 1999 in Perelet, Renat., Anil Markandya., Pamela Mason., and Tim Taylor.2001. Dictionary of Environmental Economic. Earthscan Publication: UK

[5] Yoder, R. E. 1936. A Direct Method Of Aggregate Analysus Of Soils and A Study Of The Physical Nature Of Erosion Loses. American Society of Agronomy. 28: 337-351

[6] Pimentel, D. 2006. Soil Erosion: A Food and Environmental Threat. Environment, Development and Sustainability 8: 119-137

[7] Havlin, J. L., D. E. Kissel, L. D.Maddux, M.M. Claassen, and J. H. Long. 1990. Crop Rotation and Tillage Effects on Soil Organic Carbon and Nitrogen. Soil Sci. Soc. Am. J. 54:448-452.

[8] Bilalis, D., P. Papastylianou., A. Konstans, S. Patsiali, A. Karkanis, and A. Efthimiadou. 2010. Weed- Suppressive Effects of Maize-Legume Intercropping in Organic Farming. International Journal of Pest Management. 56: 173-181

[9] Baumann DT, Bastiaans L, Kropff M. 2001. Effects of intercropping on growth and reproductive capacity of late-emerging Senecio vulgaris $L$., with special reference to competition of light. Ann Bot. 87:209-217

[10] Ritchie, J.C. and J.R. McHenry. 1990. Application of Radioactive Fallout Cesium-137 for Measuring Soil Erosion and Sediment Accumulation Rates and Pattern. Environ. Qual. 19:215-233

[11] Walling, D.E. and Q. He. 1999. Improved Models for Estimating Soil Erosion Rates from Cesium-137 Measurements. Environ. Qual. 28: 611-622

[12] Smartt, J. (ed.), 1994. The Groundnut Crop \pm a Scientific Basis for Improvement. Chapman \& Hall, London.

[13] Biabani, A., M. Hashemi, and S. J. Herbert. 2008. Agronomic Performance of Two Intercropped Soybean Cultivars. International Journal of Plant Production. 3: 215-221

[14] Hauggaard-Nielsen H, Ambus P, Jensen ES. 2001. Interspecific competition, $\mathrm{N}$ use and interference with weeds in pea-barley intercropping. Field Crop Res. 70:101-109 
[15] Food and Agriculture Organization of the United Nations (FAO). 2001.

Land and Plant Nutrition Management Service, Land and Water

Development Division. Rome 